\title{
Role of Agricultural Mechanization Technologies in Transforming Agriculture: The Case of Wheat Row Planter in Ethiopia
}

\author{
Tamrat Gebiso, ${ }^{1,}$, Ayalew Bekele ${ }^{2}$, Ephrem Boka ${ }^{1}$ \\ ${ }^{1}$ Socioeconomics Research Team, Oromia Agricultural Research Institute, Asella Agricultural Engineering Research Center, Asella, Ethiopia \\ ${ }^{2}$ Rural Energy Research Team, Oromia Agricultural Research Institute, Asella Agricultural Engineering Research Center, Asella, Ethiopia
}

\section{Email address:}

tameulove@yahoo.com (T. Gebiso)

${ }^{*}$ Corresponding author

\section{To cite this article:}

Tamrat Gebiso, Ayalew Bekele, Ephrem Boka. Role of Agricultural Mechanization Technologies in Transforming Agriculture: The Case of Wheat Row Planter in Ethiopia. American Journal of Biological and Environmental Statistics. Vol. 3, No. 1, 2017, pp. 10-19. doi: 10.11648/j.ajbes.20170301.13

Received: December 2, 2016; Accepted: December 27, 2016; Published: February 16, 2017

\begin{abstract}
Wheat is one of the major staple food crops in many parts of Ethiopia covering about $11 \%$ of total land cultivated and production share of $17 \%$ of total cereals. However, land productivity is found to be among the lowest in the country from the world which is about 2.01 tons/ha. To increase this lowest productivity, among all others, good agronomic practices is the most important and to facilitate this practice row planting was the one major action to be taken by farmers. But even though farmers were convinced to practice row planting, absence of appropriate technology was the most bottlenecks for development. To overcome the problem considerable researchers and individuals were engaged to development and adaptation of wheat row planters. However, before the embark of mass production and wider dissemination of the technologies, technical viability and socioeconomic feasibility of the technologies and selection of the best out of the options was found to be crucial activity. Therefore, this research activity was initiated to verify available prototypes for wheat row planting and recommend suitable ones for further demonstration and scaling up. Accordingly, seven row planters were collected from different sources in the country and on field evaluation were conducted in Tiyo district, Arsi zone with the presence of FRG during the major activities like planting, cultivation/weeding and harvesting and threshing. All necessary data from planting to harvest was collected. In addition to these different field days were organized to incorporate farmers' and experts' comments to strengthen the field data. Farmers' preferences, technical viability and economic data analysis using partial budgeting technique and Gross Social Return were assessed and OARI-AAMRC type wheat row planter was ranked superior to others in all aspects.
\end{abstract}

Keywords: Wheat Row Planters, Partial Budgeting, Gross Social Return, Agricultural Mechanization Technologies, Evaluation, and Farm Implements

\section{Background and Justification}

From agronomic point of view it was accepted that spacing plants both between rows and within the row have great economical advantages and some in-row crowding helps to (slightly) suppress the excessive tillering of crops such as wheat, barley, millet, and milo, and causes soybeans and field peas to set pods higher as the plants stretch a bit to try to outgrow their neighbors early in their life [4]. In many climates and crop rotations, it is also desirable to have some wider-than-equidistant gaps (the between-row spaces) to allow air flow, which results in quicker leaf drying and consequently less disease pressure. However, excessively wide row spacing creates problems for weed suppression and higher evaporation rates, as well as failing to efficiently intercept sunlight [9].

In Ethiopia wheat is the most important food crop and accordingly the crop is grown on 1.63 millions hectare annually. The annual production was estimated to 3.43 million tons which is $17 \%$ of total cereal crops production. According to [13] the average national productivity is 2.01 tons per hectare which is one of the least productivity in the 
world compared to world average wheat productivity per hectare which is 4 tons [6].

These low production and productivity of the crop are all attributed to low use of improved farm inputs (both biological, and mechanical), dependency on traditional farming system and rainfall. Taking all these issues into account, the Ethiopian agricultural research system and extension system tried to give awareness on improved agronomic practices, mainly row planting. Despite all the efforts of the government and the farmers to adopt the practices, unavailability of row planting technologies was a great challenge that faced the process.

Following the advocacy, recently demand was growing for row planting implements and methods as farmers' awareness for row planting is developing. Many attempts for wheat and teff row planting are emerging as farmers in many places are trying out with un designed items like 'masti/cans' (designed for baking injera) and various bottles and other containers. With such traditional and unverified methods of row planting, dramatic increase in yield and reduction of the quantity of seed required has been reported by farmers, DAs and experts. The research study done by [14] in high land and low lands of Arsi zone also reported that there is significant yield difference between row planted and broadcasted wheat farm $(13.9 \%)$ in high lands but with low significant difference in lowland areas. But using the local material for row planting has encountered a number of problems like absence of accuracy, labor intensiveness and tediousness of the work.

To overcome the problem agricultural mechanization research centers mainly Asella, Jimma and Melkasa have been experimenting to develop and adapt prototypes of wheat row planters. Other private companies and individuals including farmers are also producing row planting implements to commercialize on larger scale. However, such implements have to be tested and verified before distributing to farmers under farmers practical conditions even though the planters are being modified and evaluated continuously by respective research centers for further extension work. Therefore this research activity was designed to evaluate the planters which exist elsewhere in the country under the real farmers' conditions for their social, economical and technical feasibility. Accordingly, seven technologies namely AARC type from Asella research center, JAMRC animal and JAMRC hand from Jima research center, MARC from Melkasa research center, Sisay, Mamuye 3 rows and Mamuye single rows which were called after the farmers who developed them were collected and evaluated. The description of those technologies was given in the table as follows.

\section{Objectives the Study}

There are arguments among researchers and development practitioners regarding the use of mechanization technologies in developing countries in general and in Ethiopia in particular. One group argues that mechanization doesn't reduce or have little effect on overall production cost of a given output and moreover they blamed mechanization for social inefficiency. The other group claims that there is increment in net productivity as a result of use of agricultural mechanization technologies. This in line with induced innovation theory which identifies two paths of technological development in agriculture which are labor saving (mechanical innovation) and land augmenting (biological innovation) as indicated by [5]. These authors also argue that innovation in peasant agriculture should focus on biological innovation rather than mechanical one for the reason mentioned above. However, it is clear that social inefficiency can exists when there is labor displacement and it needs further numerical investigation on this issue specially for current Ethiopian case as there are complains on labor shortage. Despite these, it is also clear that there are also contribution effects of mechanization technologies in addition to their substitution effects. Therefore, the main/general objective of this activity was to assess the financial benefits of row planting using local materials/hand and conventional row planting vis-à-vis other research output row planting technologies and create strong linkage among key stakeholders for technology transfer system.

The specific objectives were:

1. To evaluate and verify available prototypes for wheat row planting and recommend suitable ones for further demonstration and pre-scaling up

2. To generate feedback on the technologies for further improvement (feedback assessment)

Table 1. Description of Respective Planters.

\begin{tabular}{|c|c|c|c|c|c|c|}
\hline Planter type & Weight & Price (ETB) & Power source & No. of operators & No. of rows per pass & Fertilizer application system \\
\hline AAMRC & 70 & 10,200 & Oxen & 1 & 4 & Yes \\
\hline JAMRC animal & 24.8 & 950 & Oxen & 1 & 4 & Yes \\
\hline MARC & 80 & 10669.49 & Oxen & 1 & 6 & No \\
\hline Sisay & 16.5 & 2870 & Oxen & 1 & 3 & No \\
\hline Mamuye 3-row & 20 & 1200 & Oxen & 2 & 3 & No \\
\hline Mamuye single row & 18 & 450 & Oxen & 1 & 1 & No \\
\hline check row & - & 381 & Oxen & 3 & 1 & NA \\
\hline check broadcast & - & 381 & Manual & 1 & - & No \\
\hline
\end{tabular}

1 Machine Cost for OARI-JAMRC type planter includes cost of other traditional (local plowing technologies as it is part of the technology to accomplish its job. 


\section{Methodology}

\subsection{Selection of Study Sites and Participating Farmers}

The wheat planter trial was conducted in wheat belt district of Arsi zone's districts namely Tiyo in three peasant associations (PAs) which were selected from the district purposively based on their accessibility and potential for wheat production. The specific sites (PAs) representing the different soil types were selected in collaboration with the respective district agricultural office. Therefore, three representative farmers were selected from the district based on their interest, accessibility of their field and capacity to allocate the required experimental land, oxen and properly manage the fields. Each experimental farmer prepared a $5 \mathrm{~m} \times 20 \mathrm{~m}$ land for each treatment. Under each experimental farmer an FRG of having 10 to 15 farmers' member were organized to make a participatory evaluation of the technologies under evaluation. The experimental and other non-experimental FRG member farmers were presented during the whole major activities like seeding, during germination count, early maturity stages field supervision and during harvest etc.

\subsection{Data Type and Methods of Collection}

In this research activity we had three types of data. The first one was effective field capacity of each operation ( $\mathrm{kg} / \mathrm{ha})$, time required to plant a plot, time per pass, field efficiency, number of rows, uniformity of seed distribution, ease of operation, depth of plantation, level of complexity etc. the second type of data was agronomic data which are germination/stand count, plant height and grain yield per hectare and the third data type was socio-economic data like: price (production cost) of each implement, cost of production per a plot, and total revenue/income from sale of grains, and farmers' view regarding suitability and affordability of the implements.

The data generated by the questionnaire which was collected during threshing period was then used to assess the preference of different planters and planting mechanisms and possible way of disseminating the newly developed and preferred planter(s) to enhance the future adoption of the technology. In addition, views of farmers were collected continuously during field operation at each season through discussion organized during field days and checklists.

\subsection{Method of Data Analysis}

The statistical analysis methods of a given research activity depends on size and nature of data at hand. In this research activity, descriptive statistics ANOVA were used. Accordingly, to identify the farmers' preference of the row planters preference ranking was employed while other data type specially seed uniformity among different row planters and within rows of a given row planter one way ANOVA where the rest data were analyzed using descriptive statistics. One way ANOVA analysis is the best way in comparing different treatments which is widely used by different authors [15], [10]. In addition to these, to conduct the economic viability of the technologies partial budgeting (farm budgetary technique) was employed.

\subsection{Farm Budgetary Technique}

[1] Explained farm budget as the quantitative expression of total farm plan summarizing the income, cost and profit (a residue of total cost from total revenue) of the given farm. Accordingly, gross margin (GM) which is the difference between total farm revenue and total variable cost (costs that vary due to machine use) was calculated. The total budgetary component of each enterprise (enterprises in this case is based on method of technological used for planting) is expressed as follows:

The profit of each wheat enterprise, was calculated using

$$
\begin{gathered}
\Pi_{i}=\Re_{i}-\left(T V C_{i}+T F C_{i}\right) \\
V C_{i}=r_{i} x_{i} \\
G M_{i}=R_{i}-V C_{i} \\
B C R_{i}=\frac{R_{i}}{T C_{i}} \\
R O R_{i}=\frac{\Pi_{i}}{T C_{i}} \\
\prod_{i}=P_{i} Q_{i}
\end{gathered}
$$

Where, $\Pi=$ net income /profit; $\mathrm{R}=$ gross revenue/income

$\mathrm{VC}_{\mathrm{i}}$-variable cost/expenses; $r_{i}$ prices of variable inputs used; $\mathrm{x}_{\mathrm{i}}=$ quantity of variable inputs used; $\mathrm{TFC}=$ total fixed cost/expenses; $\mathrm{GM}=$ Gross Margin; $\mathrm{BCR}=$ Benefit Cost Ratio

$\mathrm{ROR}=$ Rate of Return for the machine (Planter used); $\mathrm{P}_{\mathrm{i}}=$ average price of output during the year

$\mathrm{Q}_{\mathrm{i}}=$ quantity of output per each plot converted into per hectare

All the above items, cost, profit and others were first calculated for each plot $(100 \mathrm{~m} 2)$ of wheat land and then converted to per hectare of land for each technology (planter in use).

\subsection{Conceptual Framework}

\section{Description of Wheat Planting Methods}

The current wheat planting mechanisms in Ethiopia have different drawbacks since there is no precision as there is no calibrated machine to perform the activity. As a result even though there are literatures recommending the seed rates, it is difficult to maintain such recommendations. Currently, the available literatures suggest $100-132 \mathrm{~kg}$ of seed per hectare for wheat depending on germination rate, seed size and weather conditions [11]. Having seeding rates of too low or too much have their own disadvantages. For example using seeding rates of too low may lead to excessive tillering, delay in maturity, increased weed competition, and fail to make use of the plant's full yield potential. In other way, using too high 
seeding rates may increase costs, result in increased lodging, and possibly reduce yields [16].

\subsection{Planting by Broadcasting Mechanism}

In Ethiopia wheat planting has been performed by broadcasting mechanism for so many years. The system is very simple and it doesn't need any technology to perform the activity. A single person can cover with one go a minimum of 2 to 3 meters of his farm and moves with his maximum speed of walk. But since seed covering will be done by local plow called maresha, it requires more mandays. In this case a single person can manage the whole operation.

\subsection{Row Planting Mechanism}

Wheat row planting is a new technology (practice) emerging since five years in the country and it is being widely advocated by extension of the country in almost all wheat growing areas and it is also under adoption process. The practice is believed to have good responses from farmers in terms of yield advantage and farm management to conduct different agronomic practices but criticized because of absence of technology to perform such practices. The new row planters developed by different bodies have their own advantages over the broadcasting and row planting using local materials/hand such as precision of seed and fertilizer to the recommended rate, ease of operation, time saving and précised placement of the seed and fertilizer/evenly distribution of the seed and fertilizer.

\subsection{The Concept of Technology Options in Wheat Planting}

In developing the row planter by different research centers and other private organizations, there were two main objectives. The first objective was to increase land productivity and production compared to broadcasting mechanism through improved agronomic practices like crop cultivation and best precision of placement of seed which facilitate aeration and placement of fertilizer at recommended distances from the seed. In addition to this it is assumed that row planting will help farmers to have recommended plant population/seed rate per hectare with evenly distribution. In this case even though variable costs like machine cost, and other labor costs for different agronomic managements other than planting are expected to be higher than conventional broadcasting practice, it will be offset by higher land productivity. The second objective was maximization of profit by reducing labor and time required for plantation compared to local row planting practices, reducing input costs by reducing amount of fertilizer and seed to be used by using recommended amount of inputs. In this case additional production costs like machine cost and other cultivation costs are expected to be offset by low cost of labor for plantation specially compared to row planting using local materials.

The conventional row planting method which farmers are currently using is both labor and time intensive while the broadcasting method is time intensive. As it is mentioned above the objectives of developing row planters were to reduce both the labor and time required to plant a given area of wheat field. In Figure 1, two isoquants are depicted to illustrate the situation. In this case it is assumed that (Labor*Time) is equals constant which is amount of land wheat planted. The $\mathrm{K}_{\mathrm{A}}$ isoquant represents the conventional planting method characterized by labor intensive at one extreme and time intensive at the other. The use of row planter shifts the isoquant from $\mathrm{K}_{\mathrm{A}}$ to the lower isoquant $\mathrm{K}_{\mathrm{B}}$ where both labor and time required are reduced without compromising of amount of area planted in row. For example if a farmer decided to use conventional row planting, he will be required to use $\mathrm{L}_{1}$ amount of labor and the time to required will be $\mathrm{T}_{1}$ and if he preferred to use improved row planting methods the labor amount will be $\mathrm{L}_{2}$ with time required to plant the same field of $T_{2}$ which is less than $L_{1}$.

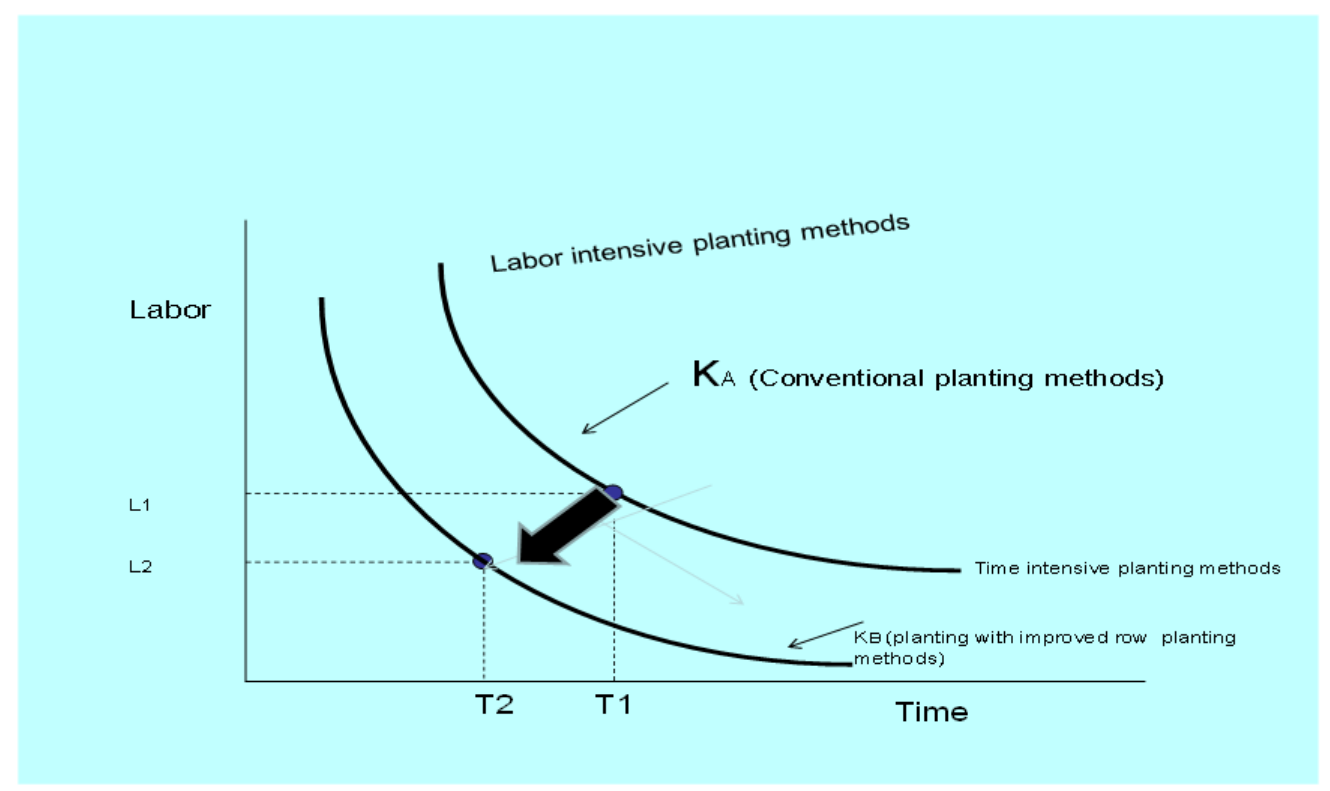

Figure 1. Row planting technology options. 
The optimum position for both methods (conventional and improved methods) will depend on the economic and social factors appropriate to a particular household and specific time and location.

\subsection{Estimation of Machine Costs in Wheat Planting}

There are two categories of machine cost in general which are annual ownership cost (also known as fixed cost) which occurs regardless of machine use, and operating costs (variable cost) which vary with the amount of the time we use the machine. To estimate such costs we need to make some assumptions about the machine's economic life, annual use, and fuel and labour prices. In our case since the machine is animal drawn, fuel cost is zero. Economic life of a machine is the number of years over which costs are to be estimated or it is machine's service life. In our case since experimental research was not done on these particular machines the researcher tried to use standardized tractor mounted planters' economic life to calculate depreciation cost and accordingly a total of $1500 \mathrm{hrs}$ of service hours was assumed and if the farmer can have a maximum of about 15 hectares of wheat farm, 12 years of economic life can be assumed for OARI-Asella type and EIAR-MARC type planters based on some research outputs [11]; [12]. For other planters we assumed five years of economic life based on some research outputs and researchers' comments which were made based on materials and production mechanism that was and should be followed. In general the total machine cost for each mechanism was summarized in Appendix 1.

Fixed costs: from the fixed cost category we only considered depreciation cost and capital interest rate but shelter, insurance and taxes were not considered. To calculate the depreciation cost, we followed American Society of Agricultural and Biological Engineers cited in [11]. But after calculating the salvage value at the end of economic life we converted the total depreciation cost of the machine into straight line formula to distribute the cost equally throughout the economic life of the machine for simplicity of computation.

Interest on capital: regardless of whether or not the money is borrowed to purchase the machine (planter), capital cost should be calculated and assigned. Here we have two types of interests. The first one is when the farmer borrow the money to purchase the machine and on the other way when he uses his own money. If he borrows from credit providers, he will be charged the rate determined by the institution and when he used his own money he will be charged an amount equals to the opportunity cost for the capital elsewhere in his farm business or the amount he would have earned when he saves the money in the bank. But sine both are possible, following [13], to compute capital interest charge we adopted the following formula:

[(purchase price-salvage value) $x$ rate of interest] $/ 2$

Operating costs: the operating costs of a machine include those costs that are incurred as a direct result of machine use and they vary with amount of machine use. These costs include fuel, lubrication and labor and repairs and maintenance costs and it is shown in Appendix 2. In our case fuel cost doesn't exist as the machines are powered by animal and lubrication costs are also insignificant and can be included in repairs and maintenance costs for simplicity. Therefore, repairs and maintenance cost of the machine is considered and according to ASAE standard [12] a given row planter can serve for about 1500 hours $(125 \mathrm{hrs} / \mathrm{yr})$ and estimated repairs and maintenance cost is $75 \%$ of its list price. Annual repair and maintenance costs were calculated and converted into per hourly basis for above two machines. But for other five machines and the local checks, we simply used the rule of thumb of $3 \%$ of total machine cost as repair and maintenance cost. Labor cost was also calculated separately and have three cost titles under machine cost calculation in general which are depreciation cost, interest charge and repair and maintenance cost.

\subsection{Estimation of Total Wheat Production Cost}

Since we are not dealing with the whole farm profitability analysis activity and we are using partial budgeting method, we only consider costs that vary due to the use of wheat planter. Therefore, under wheat production cost we only considered implicit costs which vary by use of row planters which include: wheat planter machine cost (depreciation cost), labor cost for plantation (operational cost), oxen rental cost, fertilizer and seed cost, cultivation cost, mechanical weeding costs.

\section{Results and Discussions}

\subsection{Socioeconomic Characteristics and Resource Ownership of Farmers}

The analysis of socio-economic characteristics of the respondents (Table 2) shown that the mean age of the respondents was 43 years. The result also revealed that the average family size of the household is 5.64 person and majority of the households are male headed $(81.8 \%)$ and $90.9 \%$ of them were married. Average schooling years of respondents was 8.36 and total land owned was 4.14ha. Mean share of land allocated for wheat production was 2.16 ha (i.e. $54 \%$ or 0.54 ha out of every one hectare he/she has is covered by wheat crop) which indicates that wheat is the major crop of the area. The mean Tropical Livestock Unit possession was $7.56 \mathrm{TLU}^{2}$. Most respondents (participants) have ample experience in farming (average of 21 years). About $41 \%$ of the farmers participate on nonfarm and off-farm activities with average annual income of 11159.06Birr. The correlation coefficient between total land owned and the age of Household head was found to be positive and very strong $(0.85)$ which shows that land is owned by older farmers. The price offered by farmers for the planter selected and ranked first (OARI-AAMRC) and number of oxen possessed were found to be strongly correlated $(0.57)$.

2 TLU was calculated based on [14] 
Table 2. Mean of socioeconomic and demographic variables for HHs.

\begin{tabular}{|c|c|c|c|}
\hline No. & Variables & Mean & Standard deviation \\
\hline 1 & $\begin{array}{l}\text { Offered machine price for } \\
\text { AAMRC }\end{array}$ & 7727.27 & 1663.79 \\
\hline 2 & Daily wage & 59.55 & 16.19 \\
\hline 3 & Oxen rent/day & 158.63 & 19.12 \\
\hline 4 & Age of $\mathrm{HH}$ & 43.09 & 5.92 \\
\hline 5 & Educational status of $\mathrm{HH}$ & 8.36 & 3.44 \\
\hline 6 & No. of working family & 4.9 & 1.51 \\
\hline 7 & Total family & 5.64 & 1.29 \\
\hline 8 & No. of hired labor & 0.64 & 0.92 \\
\hline 9 & $\begin{array}{l}\text { Land allocated for wheat } \\
\text { production }\end{array}$ & 2.16 & 0.60 \\
\hline 10 & Total wheat production & 83.09 & 29.73 \\
\hline 11 & Wheat sold & 52.73 & 27.14 \\
\hline 12 & $\begin{array}{l}\text { Yield } \mathrm{d} / \mathrm{ce} \mathrm{b} / \mathrm{n} \text { row and } \\
\text { broadcasting }\end{array}$ & 9.10 & 4.61 \\
\hline 13 & Total land owned & 4.14 & 1.53 \\
\hline 14 & $\begin{array}{l}\text { Land share allocated for } \\
\text { wheat }\end{array}$ & 0.54 & 0.09 \\
\hline 15 & Wheat land share row planted & 0.31 & 0.27 \\
\hline 16 & Tropical livestock unit (TLU) & 7.56 & 2.81 \\
\hline 17 & Off/nonfarm income & 11159.06 & 1.93 \\
\hline
\end{tabular}

\subsection{Farmers, Preference and Comments}

Assessment was made about farmers' preferences and comment about row planting and row planters in general and it was summarized. Accordingly, all the farmers know about the advantages of row planting and were (100\%) interested in row planting and willing to plant their field in row but the main problem they presented was the absence of row planting technology. Almost all, (89\%) of the respondents decided not to plant in row unless they get some technology. The main reason was that the current practice of using hand or some other local material for row planting is tiresome, time and labor consuming which over hits the production cost and in addition the seed uniformity is very poor. In this case, the seed rate was also almost similar to broadcasting method.

Pair wise ranking method was used to identify the features of planters that the farmers give more weight (attention). Accordingly, it was found that they gave more attention to time and seed saving capacity of the planter at the first rank and labor saving and seed uniformity was put the second and third most important features (Table 3).

Table 3. Rank given to planters'features.

\begin{tabular}{lllll}
\hline No. & Planters feature & Average Rank & Rank & $\begin{array}{l}\text { Standard } \\
\text { deviation }\end{array}$ \\
\hline 1 & Seed saving & 1.909 & 1 & 0.83 \\
2 & Time saving & 1.909 & 2 & 0.94 \\
3 & Labor saving & 2.09 & 3 & 1.21 \\
4 & Seed uniformity & 2.36 & 4 & 1.21 \\
5 & Ease operation & 3.09 & 5 & 1.30 \\
6 & Weight of planter & 4.18 & 6 & 0.75 \\
7 & Price of machine & 4.27 & 7 & 1.27 \\
\hline
\end{tabular}

From the interviewed farmers, all farmers want to acquire the planter at different price ranging from $5500 \mathrm{ETB}^{3}$ to

3 ETB (Birr) is Ethiopian currency where according to report of National Bank of
10000 ETB. The mean price attached to planter ranked first (OARI-AAMRC type) was $7727.27(1663.79)^{* 4}$ ETB while the price of the planter fixed by the center's team of experts including $25 \%$ profit margin was 10,200 ETB. One sample ttest was done and mean difference was found to be negative and significant at $99 \%(\mathrm{p}$-value $=0.001)$ which implies that the price of the machine attached by the center is much higher than the mean price offered by the farmers.

Based on the engineering and economist technical team of evaluators, and farmers' preferences, OARI-AAMRC type wheat planter was ranked first. From the experts' point of view, ease of operation (which was defined as easiness to turn at each turning point, seed uniformity, level of row making) and level of complexity (which was also defined by its attributes like simplicity for maintenance, adjustment, and ease of understandability by a farmer) and technology completeness (mainly fertilizer application mechanism) were the main evaluation criteria which was considered during machine assembly, operation on fields, simple maintenance whenever problems occurred and during field supervision to take agronomic data. Based on this, even though EIARMARC type row planter was competent in other criteria, it lacks fertilizer application mechanism and seed rate was also very high compared to recommendation and ranked next to OARI-AAMRC planter type. Therefore, farmers commented that both planters were good and possible to use them interchangeably if these two issues have got solutions.

It is known that the basic agronomic criteria for row planting is seed uniformity and when we assessed the planters from this point of view, the ANOVA result revealed that EIAR-MARC was found to be of superior quality with mean germination count of 48 and standard deviation of 3.46 followed by OARI-AAMRC which has 53.67 and 5.51 mean germination count and standard deviation respectively. The overall F-value from ANOVA table (Table 4) also revealed that there is high mean variation within and between each planting methods $(\mathrm{p}=0.002)$.

Table 4. ANOVA Result for seedling uniformity.

\begin{tabular}{llllll}
\hline & Sum of square & df & mean square & F & sig. \\
\hline Between Groups & 13386.74 & 8 & 1673.34 & 5.30 & 0.002 \\
Within Groups & 5681.33 & 18 & 315.63 & & \\
Total & 19068 & 26 & & & \\
\hline
\end{tabular}

\subsection{Financial Profitability (Birr/ha) of Wheat Row Planting in Arsi Zone}

Results of the partial budgeting analysis are shown in Table 5. The cost of wheat planting per hectare was lower for OARI-JAMRC animal drawn planter (891.39 birr/ha) mainly due to lower machine cost (22.87 birr/ha) and lowest seed cost (579.92 birr/ha) which is due to lowest seed rate of the machine $(49.69 \mathrm{~kg} / \mathrm{ha})$ much below the recommended rate $(125 \mathrm{~kg} / \mathrm{ha})$ Table 6 . This implies that around $60 \%$ of the land will be left unplanted. The two checks (row planting by local

Ethiopia's exchange rate $1 \mathrm{USD}=22.8075 \mathrm{ETB}$ as at $2016-12-21$

4 The number in the parenthesis is standard deviation 
materials and broadcasting) have recorded the highest seed rate $(200 \mathrm{~kg} / \mathrm{ha}$ for both) followed by EIAR-MARC which has seed rate of $171.51 \mathrm{~kg} / \mathrm{ha}$. Subtotal cost for planting was found to be highest for row planting system using local methods/hand (3794.11 Birr/ha) followed by broadcasting method and Mamuye single row planter. Total cost/ha that vary was highest for row planting by local materials (5234.00 Birr/ha) followed by broadcasting method (4296). Labor cost was highest for row planting by local materials $(760.50$ Birr/ha) followed by OARI-JAMRC hand operated planter type (358.35 Birr/ha).

Table 5. Mean values of continuous variables of machines.

\begin{tabular}{llllllll}
\hline No. & Planter type & Time/ha & Yield/ha & $\begin{array}{l}\text { Seed rate/ha } \\
\text { (in Kg) }\end{array}$ & $\begin{array}{l}\text { Seedling/meter of row } \\
\text { (planting uniformity)* }\end{array}$ & $\begin{array}{l}\text { Total seed } \\
\text { cost }^{5}\end{array}$ & $\begin{array}{l}\text { Plant population/ha } \\
\text { (50mx200m) }\end{array}$ \\
\hline 1 & AAMRC & $8.33 \mathrm{hrs}$ & 40.8000 & 111.4167 & $53.67(2.51)$ & 1300.23 & $2,000,000.00$ \\
2 & JAMRC animal & $10.56 \mathrm{hrs}$ & 25.3333 & 49.6933 & $16.33(7.77)$ & 579.92 & 539333.00 \\
3 & JAMRC hand & $23.89 \mathrm{hrs}$ & 36.3333 & 127.5733 & $84.33(17.56)$ & 1488.78 & 2516666.00 \\
4 & MARC & $8.89 \mathrm{hrs}$ & 38.8000 & 171.5067 & $48.00(3.46)$ & 2001.48 & 2465333.00 \\
5 & Sisay & $15.00 \mathrm{hrs}$ & 35.6333 & 101.3267 & $50.33(37.21)$ & 1182.48 & 1671333.00 \\
6 & Mamuye 3-row & $13.89 \mathrm{hrs}$ & 36.8333 & 110.7467 & $47.67(17.21)$ & 1292.41 & 1671333.00 \\
7 & Mamuye single row & $27.22 \mathrm{hrs}$ & 36.9667 & 139.2467 & $55.33(17.90)$ & 1625.01 & 1574666.00 \\
8 & check row & $33.80 \mathrm{hrs}$ & 36.6667 & 200.0000 & $93.33(19.55)$ & 2334.00 & 2807333.00 \\
9 & check broadcast & $27.02 \mathrm{hrs}$ & 39.6667 & 200.0000 & $80.33(6.81)$ & 2334.00 & 2451333.00 \\
\hline
\end{tabular}

Number in parenthesis is standard deviation

The lowest labor cost was for OARI-AAMRC which is $62.48 \mathrm{Birr} /$ ha which is about $8 \%$ compared to row planting system using local methods/hand. Use of OARI-AAMRC row planter frees about 2-12 man days of unskilled labor per hectare (Table 6), which is supplied predominantly by the family and partly by hired labor. The highest labor is needed when the farmer is using row planting system using local methods/hand which is about 12 man-days per hectare. Finally, the net income after costs that vary was highest for OARI-AAMRC type row planter which was about ETB of 37310.

Table 6. Mean labor and oxen-hours/hectare and freed man day by AAMRC compared to others.

\begin{tabular}{|c|c|c|c|c|c|}
\hline No. & Planter type & No. of operators & Man day freed by AAMRC planter type & Labor-hrs & Oxen-hrs \\
\hline 1 & AAMRC & 1 & 0 & $8.33 \mathrm{hrs}$ & $8.33 \mathrm{hrs}$ \\
\hline 2 & JAMRC animal & 1 & 0.32 & $10.56 \mathrm{hrs}$ & $10.56 \mathrm{hrs}$ \\
\hline 3 & JAMRC hand & 2 & 5 & $47.78 \mathrm{hrs}$ & $23.89 \mathrm{hrs}$ \\
\hline 4 & MARC & 1 & 0 & $8.89 \mathrm{hrs}$ & $8.89 \mathrm{hrs}$ \\
\hline 5 & Sisay & 1 & 1 & $15.00 \mathrm{hrs}$ & $15.00 \mathrm{hrs}$ \\
\hline 6 & Mamuye 3-row & 2 & 2 & $27.78 \mathrm{hrs}$ & $13.89 \mathrm{hrs}$ \\
\hline 7 & Mamuye single row & 1 & 2 & $27.22 \mathrm{hrs}$ & $27.22 \mathrm{hrs}$ \\
\hline 8 & check row & 3 & 12 & 101.4hrs & $33.80 \mathrm{hrs}$ \\
\hline 9 & check broadcast & 1 & 2 & $27.02 \mathrm{hrs}$ & $27.02 \mathrm{hrs}$ \\
\hline
\end{tabular}



Figure 2. AAMRC animal drawn wheat row planter.

5 Seed cost $/$ ha is calculated using seed price $/ \mathrm{kg}$ of $11.67 \mathrm{ETB} / \mathrm{kg}$ based on data from Tiyo district's cooperative development office.

6 Machine Cost for OARI-JAMRC type planter includes cost of other traditional (local plowing technologies as it is part of the technology to accomplish its job. 


\subsection{Gross Social Returns from the Row Planting Machines}

The quantitative impact of adopting row planting by wheat growing farmers was assessed by using ex ante impact assessment technique. An ex ante impact assessment/evaluation technique attempts to measure the intended impacts of future intervention given a potentially targeted area's current situation [11].

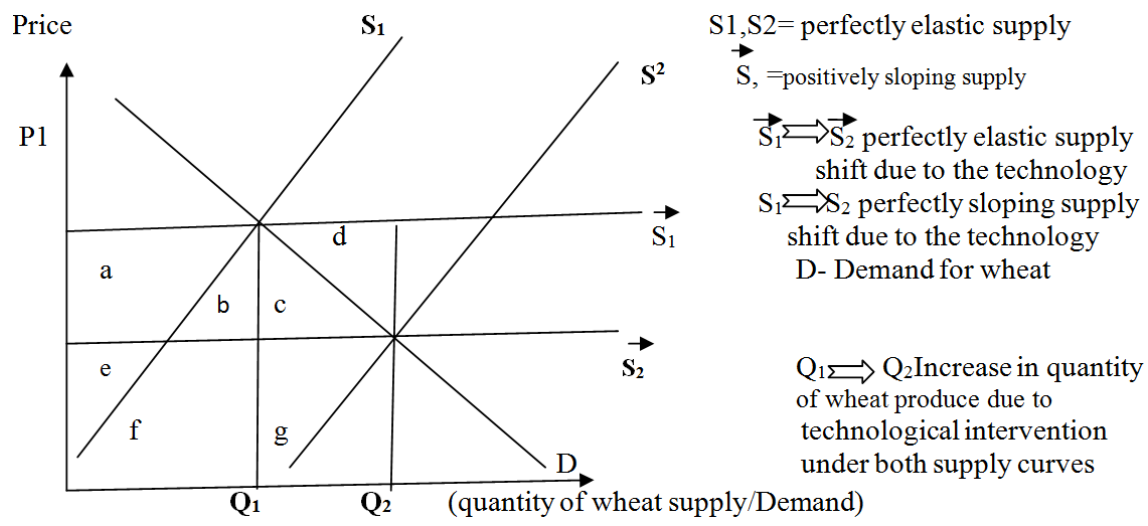

Figure 3. Gross Social Returns to the row planter under two different supply schedules.

The net benefit to the society due to the use of row planting machines is the total change in both consumers' and producers' surplus. Therefore, as it is illustrated above the net benefit when the supply is perfectly elastic to price and demand curve is $\mathrm{D}$, is $a+b+c$ and when the supply is positively sloping, the total area of $b+c+f+g$ will be the net benefit of the society due to technological intervention. However, since the commodity is food item we expect positively sloping supply curve in our case and if we took the perfectly elastic curve while it is positively slopping curve, we may overestimate the consumers' surplus by the area $d$.

The value of net income after the cost that vary due to technological intervention (in this case we took OARI-
By "gross social return" we mean that the value/amount of row planting cost reduced and production amount increased due to the use of row planters. We followed [16] analytical framework to compute the value of "gross social return". The framework used the concepts of consumers' and producers' surplus as it is illustrated in figure 2 below.

of wheat produce due to

technological intervention

under both supply curves

AAMRC planter) in relative to each technology with respect/against to the rest planters: OARI-JAMRC animal drawn, OARI-JAMRC manual, EIAR-MARC wheat planter, Sisay type, Mamuye 3-row, Mamuye single row wheat planter, Check (local row planting method) and Check (broadcasting method) were $14572.00,5142.00,2707.00$, $5178.00,4114.00,4558.00,3283.00$ and $5641.00 \mathrm{Birr} / \mathrm{ha}$ respectively. The total area coverage for wheat crop in the country is based on the national level estimate of CSA (2014) for the cropping season of 2013/14 which was 1,605,654 ha. The impact of the technological intervention (GSR) for the selected technology was calculated/ analyzed and presented at different adoption level in Table 7.

Table 7. Financial Profitability (Birr/ha) of wheat row planting technologies in Arsi zone

\begin{tabular}{|c|c|c|c|c|c|c|c|c|c|}
\hline Variables & AAMRC & JAMRC I & JAMRC II & MARC & Sisay & MamuyeI & Mamuye II & Check I & Check II \\
\hline & OARI & (animal) & (hand) & (EIAR) & (farmer) & (Three rows) & (Single row) & row & non row \\
\hline Yield (qt/ha) & 40.80 & 25.33 & 36.33 & 38.80 & 35.63 & 36.83 & 36.97 & 39.67 & 36.34 \\
\hline Gross return $^{\mathrm{a}}$ & 40379 & 25069 & 35955 & 38400 & 35263 & 36450 & 36589 & 39261 & 35965 \\
\hline \multicolumn{10}{|l|}{ Cost of wheat row planting: } \\
\hline Seed cost & 1300.23 & 579.92 & 1488.78 & 2001.48 & 1182.48 & 1292.41 & 1625.01 & 2334.00 & 2334.00 \\
\hline Labor cost (planting) & 62.48 & 79.20 & 358.35 & 66.68 & 112.50 & 208.35 & 204.15 & 760.50 & 202.65 \\
\hline Oxen-day cost/ha & 165.18 & 209.40 & 473.74 & 176.29 & 297.45 & 275.44 & 539.77 & 670.25 & 535.81 \\
\hline $\begin{array}{l}\text { Subtotal cost for planting } \\
\text { Weeding cost }\end{array}$ & 1628.67 & 891.39 & 2347.07 & 2357.31 & 1690.58 & 1814.23 & 2396.86 & 3794.11 & 3095.93 \\
\hline -Mechanical weeding & 600.00 & 600.00 & 600.00 & 600.00 & 600.00 & 600.00 & 600.00 & 600.00 & 1200.00 \\
\hline -Cultivation & 840.00 & 840.00 & 840.00 & 840.00 & 840.00 & 840.00 & 840.00 & 840.00 & $0^{8}$ \\
\hline Total cost that vary & 3069 & 2331 & 3787 & 3797 & 3131 & 3254 & 3837 & 5234 & 4296 \\
\hline Net income ${ }^{9}$ & 37310 & 22738 & 32168 & 34603 & 32132 & 33196 & 32752 & 34027 & 31669 \\
\hline
\end{tabular}

a: average price of wheat of 989.69 Birr was taken and the data was taken from Asella town trade and market development office

7 Weedicide application is all the same for all planting systems; cultivation is only needed when row plating is there and labor for mechanical weeding is 14 man-days for row planted crop since cultivation will weed out most weeds and 20 man-days for broadcasted fields.

8 When the crop is planted by broadcasting it doesn't need cultivation only chemical and mechanical weeding is needed

9 This net income is only the income after costs that vary and other costs like land cost, land preparation cost, different chemicals cost, harvesting and threshing, transportation storage etc costs are not included. 
Table 8. Annual Gross Social Return (GSR) to OARI-AAMRC wheat row planter.

\begin{tabular}{|c|c|c|c|c|c|c|c|c|}
\hline \multirow{2}{*}{$\begin{array}{l}\text { Annual GSR } \\
\text { (2014) at } \\
\text { different } \\
\text { adoption } \\
\text { rates }\end{array}$} & \multicolumn{8}{|c|}{ Estimated Net Return against } \\
\hline & $\begin{array}{l}\text { OARI- } \\
\text { JAMRC } \\
\text { animal drawn } \\
\text { @14572/ha } \\
\end{array}$ & $\begin{array}{l}\text { OARI-JAMRC } \\
\text { manual @5142 } \\
\text { Birr/ha }\end{array}$ & $\begin{array}{l}\text { EIAR-MARC } \\
\text { @2707 Birr/ha }\end{array}$ & $\begin{array}{l}\text { Sisay @5178 } \\
\text { Birr/ha }\end{array}$ & $\begin{array}{l}\text { Mamuye 3- } \\
\text { row @4114 } \\
\text { Birr/ha }\end{array}$ & $\begin{array}{l}\text { Mamuye } \\
\text { single row } \\
\text { @ } 4558 \\
\text { Birr/ha } \\
\end{array}$ & $\begin{array}{l}\text { Local row } \\
\text { planting } \\
\text { method @3283 } \\
\text { Birr/ha }\end{array}$ & $\begin{array}{l}\text { Broadcasting } \\
\text { method @ } 5641 \\
\text { Birr/ha }\end{array}$ \\
\hline $100 \%$ & 23397590088 & 8256272868 & 4346505378 & 8314076412 & 6605660556 & 7318570932 & 5271362082 & 9057494214 \\
\hline $75 \%$ & 17548192566 & 6192204651 & 3259879034 & 6235557309 & 4954245417 & 5488928199 & 3953521562 & 6793120661 \\
\hline $50 \%$ & 11698795044 & 4128136434 & 2173252689 & 4157038206 & 3302830278 & 3659285466 & 2635681041 & 4528747107 \\
\hline $25 \%$ & 5849397522 & 2064068217 & 1086626345 & 2078519103 & 1651415139 & 1829642733 & $1,317,840521$ & 2264373554 \\
\hline
\end{tabular}

From the Table 9 above, it can be seen that adoption of OARI-AAMRC type wheat row planter on $25 \%$ of the current wheat field will have advantage of $1,317,840521$ Birr/year (GSR/year) and the adoption of the technology has greatest advantage (GSR) over/ against OARI-JAMRC animal drawn wheat row planter which is about 5.8 billion Birr per annum.

\section{Conclusion and Recommendations}

\subsection{Conclusion}

Due to the effort made by researches and extension services, farmers of Ethiopia almost adopted technologies especially high yielding variety, optimum fertilizer rate utilization, and weed management practices and chemicals. The use of mechanical technologies (Agricultural mechanization technologies) whether it is pre-harvest or post harvest was not given attention and was not included in extension service packages. But, in recent years the importance of such technologies (specially the advantages of row planter and row planting wheat and teff crops) are magnified by farmers and extension service providers.

In this study advantage of row planting technologies against conventional broadcasting and conventional row planting using hand or local materials was assessed. In addition to this selection of best technology out of the seven row planters was done. Considering farmers' preference rate, team of experts and researchers technical feasibility rating criteria, and socioeconomic criteria, OARI-AAMRC animal drawn wheat planter and EIAR-MARC were selected and ranked first and second respectively. It can be seen from partial budgeting result table that the net income after costs that vary for OARI-AAMRC type planter and for that of EIAR-MARC type were found to be $37310 \mathrm{birr} / \mathrm{ha}$ and 34603 birr/ha, respectively. The least net income was found for OARI-JAMRC animal drawn planter which was 22738 birr/ha. The gross social returns (GSR) of first ranked technology against the other technologies were also very significant. For instance, the GSR of OARI-AAMRC against EIAR-MARC planter were 4346505378, 3259879034, 2173252689 , and 1086626345 birr with $100 \%, 75 \%, 50 \%$ and $25 \%$ adoption of the technology, respectively.

\subsection{Recommendations}

Based on the criteria set jointly by the participant farmers and researches, AAMRC type planter was selected as first. Therefore, team of researchers recommended the systematic transfer of this technology for further multiplication and wider dissemination. But, before that proper design and production manual have to be prepared and intensive training has to be given to potential manufacturers/multipliers. Upon delivery to end-users, to reduce technology backfire, training of trainers (TOT) has to be given to development agents to enable them at least to give solutions for minor disability, assembling, servicing and minor maintenance and to provide training for farmers on how to use the technology properly.

\section{Appendix}

Appendix 1. Machine cost calculated.

\begin{tabular}{|c|c|c|c|c|c|c|c|}
\hline Machine Type & $\begin{array}{l}\text { capital } \\
\text { interest }^{10}\end{array}$ & $\begin{array}{l}\text { Total accumulated } \\
\text { depreciation cost }{ }^{11}\end{array}$ & $\begin{array}{l}\text { Depreciation } \\
\text { cost }\end{array}$ & $\begin{array}{l}\text { How to calculate } R \\
\& M \text { cost }^{12}\end{array}$ & $\begin{array}{l}\text { Repair and } \\
\text { maintenance } \\
(\mathrm{R} \& M) \text { cost } \\
\end{array}$ & $\begin{array}{l}\text { total } \\
\text { machine } \\
\text { cost/annum }\end{array}$ & $\begin{array}{l}\text { machine cost } \\
\text { calculated on hourly } \\
\text { basis }\end{array}$ \\
\hline AAMRC & 347.82 & $10200 * 62 \%$ & 527 & $10,200 * 75 \% / 12$ & 637.5 & 1512.3 & 12.09856 \\
\hline JAMRC animal & 52.25 & 950 & 190 & $950 * 3 \%$ & 28.5 & 270.75 & 2.166 \\
\hline JAMRC hand ${ }^{13}$ & 26.46 & $481^{*}$ & 96.2 & $481 * 3 \%$ & 14.43 & 137.09 & 1.09672 \\
\hline MARC & 368.83 & $10669.49 * 62 \%$ & 551.26 & $10669.49 * 75 \% / 12$ & 666.84 & 1586.9 & 12.69544 \\
\hline Sisay & 157.85 & 2870 & 574 & $2870 * 3 \%$ & 86.1 & 817.95 & 6.5436 \\
\hline Mamuye single row & 24.75 & 450 & 90 & $450 * 3 \%$ & 13.5 & 128.25 & 1.026 \\
\hline
\end{tabular}

10 Following Pflueger Burton, 2015, [formula: (purchase price-salvage value)x rate of interest ]/2 was used

11 Economic life of 12 years is estimated for OARI-AAMRC and EIAR-MARC type planters and American Society of Agricultural and Biological Engineers was followed to calculate depreciation amount and economic life;

12 For OARI-AAMRC and EIAR-MARC planters we followed American Society of Agricultural Engineers data on Agricultural Machinery Management data (ASAE D497.4MAR99) and for the rest we followed: Pflueger, Burton, 2005.

13 Machine Cost for OARI-JAMRC manual type planter includes cost of other traditional (local plowing technologies as it is part of the technology to accomplish its job. 


\begin{tabular}{lllllll}
\hline Machine Type & $\begin{array}{l}\text { capital } \\
\text { interest }^{\mathbf{1 0}}\end{array}$ & $\begin{array}{l}\text { Total accumulated } \\
\text { depreciation cost }^{\mathbf{1 1}}\end{array}$ & $\begin{array}{l}\text { Depreciation } \\
\text { cost }\end{array}$ & $\begin{array}{l}\text { How to calculate R } \\
\text { \& M cost } \text { R }^{2}\end{array}$ & $\begin{array}{l}\text { Repair and } \\
\text { maintenance } \\
\text { (R\&M) cost }\end{array}$ & $\begin{array}{l}\text { total } \\
\text { machine } \\
\text { cost/annum }\end{array}$ \\
\hline check row & 20.96 & 381 & 76.2 & $381 * 3 \%$ & 11.43 & $\begin{array}{l}\text { machine cost } \\
\text { calculated on hourly } \\
\text { basis }\end{array}$ \\
check broadcast & 20.96 & 381 & 76.2 & $381 * 3 \%$ & 11.43 & 108.59 \\
\hline
\end{tabular}

*machine price must include price of local farm implements' cost as it is a complementary for this machine to operate.

Appendix 2. Estimation of local erf-maresha and beam attached implement's cost.

\begin{tabular}{lll}
\hline No. & Implement part & Price $^{\mathbf{1 4}}$ (Birr) \\
\hline 1 & Erf & 16.00 \\
2 & Diggir & 40.00 \\
3 & Weggel & 30.00 \\
4 & Maresha & 180.00 \\
5 & Mofer (beam) & 100.00 \\
6 & yoke (kenber) & 120.00 \\
7 & Ropes & 15.00 \\
& Total & 381.00 \\
\hline
\end{tabular}

\section{References}

[1] Alimi T, Manyong VM. Partial budget analysis for on-farm research IITA research guide. P. 65. 2000.

[2] American Society of Agricultural Engineering Standards ASAE D497.4 MAR99. Agricultural Machinery Management Data. 2000.

[3] Burton Pflueger. Farm Financial Management (How to calculate Machinery Ownership and operating costs) SDSU college of Agricultural and Biological Sciences publications http://agbiopubs.sdstate.edu/articles/EC920e.pdf. 2005.

[4] G. A. Stewart and T. J. Vyn. Evaluation of row crop planter modifications for corn production within conservation tillage systems. Final Report on SWEEP-TED Project. DSSC No. XSE90-00079-302 Contract No. 01686-0-0085/01-XSE. Crop Science Department, University of Guelph $\mathrm{http} / / /$ www.ag.ndsu.edu/burkecountyextension/crops/howmany-seeds-per-acre (accessed on January, 05/2015).

[5] Hayami, Y., and V. W. Ruttan. Agricultural Development: An International Perspective. Baltimore, Maryland: Johns Hopkins. 1985.

[6] Jelle Bruinsma. "By how much do land, water and crop yields need to increase by 2050?" Paper presented at the FAO Expert Meeting, 24-26 June 2009, Rome, on "How to Feed the World in 2050". The resource outlook to 2050. 2009.

[7] Khandker, Shahidur R. Handbook on impact evaluation: quantitative methods and practices. 2010.

[8] Kossila, V. The availability of crop residues in developing countries in relation to livestock populations (access on $8 / 18 / 2015$ ) available on http://www.fao.org/wairdocs/ilri/x5495e/x5495e03.htm\#TopO fPage. 1998.

[9] Lee, C. and J. Herbek. Wheat Yield Response to Wide Rows. Wheat Science Research Report. Pages 1-2. 67. Maintain
Kentucky soybean rust commentary and KY-specific documents on USDA Soybean Rust Public Website, present 68, 2005.

[10] Maurya V. N., Singh B., Vashist S., Arneja C. S., Ogubazghi G. and Shukla K. K.., Food security evaluation of grain and sugar yields of improved sweet sorghum varieties for sustainable renewable energy supply using matrix correlation, American Journal of Biological and Environmental Statistics, Science Publishing Group, USA, Vol. 1(1), pp.38-45, 2015.

[11] Robert N. Klein, Drew J. Lyon and Greg R. Kruger. Seeding rates for winter wheat in Nebraska: university of Nebraska Lincoln Extension, Institute of Agriculture and Natural Resource. (http://extension.unl.edu/publication. 2011).

[12] Schemiz A. and Seckler D. Mechanized agriculture and social welfare. Amer. J. of Ag. Econ. Vol. 52, Number 4, pp. 569577. 1970.

[13] The Federal Democratic Republic of Ethiopia Central Statistical Agency Agricultural Sample Survey. Volume I report on area and production of major crops. 2014.

[14] Tolesa A., Bezabih E., Jema H., and Belaineh L. Impact of Wheat Row Planting on Yield of Smallholders in Selected Highland and Lowland Areas of Ethiopia. International Journal of Agriculture and Forestry. 4 (5): pp. 386-393 2014.

[15] Maurya Vishwa Nath, Singh Bijay, Vashsit Swammy Ogubazghi Ghebrebrhan, and Singh Vijay Vir. Effectiveness performance analysis of soil minerals $(\mathrm{Fe} / \mathrm{Zn})$ on soil fertility and cropping patterns using $\mathrm{x}$-ray fluorescence spectrometer (XRF) and ANOVA method, American Journal of Biological and Environmental Statistics. Vol. 1 (1), pp. 9-18, 2015.

[16] William Edwards, Ag Decision Maker. Estimating Farm Machinery Costs. File A3-29, Iowa State University. Revised Extension Publication PM-710, May 2015. http://www.extension.iastate.edu/agdm/cdmachinery.html.

14 Some farmers buy the items completely from market while other may prepare the wooden product implement parts and the prices were collected from ten farmers from different market areas and average was taken during the primary data collection. 